\title{
Modification and replacement of Mesozoic lithospheric mantle beneath the Cathaysia Block, South China
}

\author{
HUI ZHANG ${ }^{* 12}$, YAOQI ZHOU ${ }^{1}$, JIANPING ZHENG ${ }^{2}$ \\ ${ }^{1}$ School of Geosciences, China University of Petroleum, \\ Qingdao 266580, China \\ ${ }^{2}$ School of Earth Sciences, State Key Laboratory of \\ Geological Processes and Mineral Resources, China \\ University of Geosciences, Wuhan 430074, China \\ *Corresponding author: upc_zhanghui@163.com
}

Compared to the research on the Cenozoic volcanichosted mantle xenoliths from the Cathaysia Block, the peridotite carried by the Mesozoic basalts from this block remains little studied. Here, we report mineral chemistry and water contents of peridotite xenoliths entrained by Mesozoic basalts from the Daoxian area in the Cathaysia Block, to investigate the water distribution and the lithospheric mantle modification during the Mesozoic.

The peridotites, derived from a fertile lithosphere mantle $(\mathrm{Mg} \#$ of olivine $=88.0-89.3)$, consist of (spinel) lherzolites and display porphyroclastic textures. Clinopyroxenes in the lherzolites show LREE-depleted patterns, exhibit negative anomalies in $\mathrm{Ba}, \mathrm{Nb}, \mathrm{Pb}, \mathrm{Sr}, \mathrm{Zr}$ and $\mathrm{Ti}$, and positive anomalies in $\mathrm{Th}$ and $\mathrm{U}$, and record low degrees of melt extraction (e.g., $1-5 \%$ fractional melting) followed by weak silicate melt metasomatism. The water contents of clinopyroxenes and orthopyroxenes in the xenoliths are 182$417 \mathrm{ppm}$ and 53-123 ppm, respectively. Calculated wholerock water contents, based on the mineral modes and partition coefficients, are $35-82 \mathrm{ppm}$. The contents are similar to those estimated for the MORB source. The studied Daoxian area is located in the Ningyuan-Jianghua fault. The fault is considered to be a weak zone in the lithospheric mantle and provided a channel for the asthenospheric upwelling.

Considering all the evidence, we propose that the lithospheric mantle beneath the Cathaysia Block during the Mesozoic was heterogeneously modified by the upwelling of asthenosphere, which was preferentially accreted as juvenile SCLM along translithospheric weak zones and partially left the residual ancient lithospheric mantle during the major SCLM replacement event.

Keywords: Mesozoic lithosphere; Peridotite xenoliths; Cathaysia Block 